TEXAS AGRICULTURAL EXPERIMENT STATION

A B. CONNER, DIRECTOR,

College Station, Texas

BULLETIN NO. 618

SEPTEMBER 1942

\title{
STATE AND LOCAL FINANCIAL RELATIONS IN TEXAS
}

H. C. BRADSHAW

Division of Farm and Ranch Economics

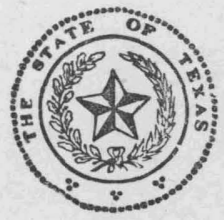

LIBRARY Egricultural \& Nechanical Gallegre日fTexar College Station, Texas

AGRIOULTURAL AND MECHANICAL COLLEGE OF TEXAS T. O. Walton, President 
[Blank Page in Original Bulletin] 
The financial problems of the State and local governments are related in a variety of ways. The counties assess and collect certain State taxes, the school districts receive State aids which are voted by the Legislature, and all units are subject to State laws on budgeting and related financial procedures. If wasteful expenditures lead to excessive taxation in one unit of government, the difficulty of collecting taxes increases in other units occupying the same area. On the other hand, good financial practices in one unit of government tend, by example, to promote good practices in other units.

The problem of State and local financial relations, therefore, exists and cannot be avoided. The officials of the two levels of government must consult each other, must initiate actions which affect each other, and must share certain responsibilities. The resulting relations between public officials and the governments which they represent are not an end in themselves, but they are a necessary tool of procedure which assists materially in operating the 7,000 units of government in Texas. Furthermore, these relations provide one of the best opportunities for the improvement of government in all its phases.

The present pattern of State and local financial relations suffers greatly from a lack of coordination. On the one hand, actions which need to be taken are ignored, while on the other hand, actions which only partially satisfy a need are duplicated. While each session of the Legislature is confronted with numerous bills affecting this situation, relatively few of the bills attempt to coordinate the many related phases of the problem.

This bulletin outlines the State and local relations growing out of the general laws respecting budgeting, assessing and collecting taxes, accounting, auditing, public reporting, and the management of debts. In addition, contributions of the associations of public officials which have cooperated in seeking solutions to various phases of the problem are recognized and discussed.

On the basis of this study, it is evident that State and local financial relations in Texas can be improved in several respects. The section entitled summary and conclusions outlines the changes which this analysis indicates would be desirable. Fortunately, the coordinated system which is suggested would cost no more, and possibly less, than the present inadequate system is costing the citizens of Texas. 


\section{CONTENTS}

Page

Introduction

Sources of Information and Method of Handling

Financial Relations in Budgeting. 6

Financial Relations in Assessing and Collecting Taxes

Financial Relations in Accounting.

Financial Relations in Auditing 13

Financial Relations in Public Reporting 16

Financial Relations in the Management of Debts 18

Differing Fiscal Years Complicate the Problem. 20

Improvements Made Through Associations of Local Officials and Other Organizations

Summary and Conclusions 23

Studies of Taxation and Government Made by the Texas Agricultural Experiment Station 


\title{
STATE AND LOCAL FINANCIAL RELATIONS IN TEXAS ${ }^{1}$
}

\author{
H. C. Bradshaw \\ Economist in Farm Taxation \\ Division of Farm and Ranch Economics ${ }^{2}$
}

According to recent compilations, there are 7,685 units of government actually operating in Texas. These include the State itself, 254 counties, 560 cities, 6,580 school districts, and 292 water and other special districts. Each of these units has some sort of governing board; assesses and collects taxes; and provides one or more services.

The State and the local units operate within a common area and have a common body of citizens and resources. Each citizen is subject to the operations of the State, the county, and the school district. In addition, more than half the citizens of Texas must support city governments, and a considerable number must support water or other special districts.

The financial problems of the State and local governments are related in a variety of ways. The counties assess and collect certain State taxes, the school districts receive State aids which are voted by the Legislature, and all units are subject to State laws on budgeting and related financial procedures. If wasteful expenditures lead to excessive taxation in one unit of government, the difficulty of collecting taxes increases in other units occupying the same area. On the other hand, good financial practices in one unit of government tend, by example, to promote good practices in other units.

The problem of State and local financial relations, therefore, exists and cannot be avoided. The financial processes of the State and local governments are inseparably intertwined; the officials of the two levels of government must consult each other, must initiate actions which affect each other, and must share certain responsibilities. In view of this fact, the problem becomes one of organization. How should the work of the State and local governments be organized in order to insure the best performance at each level? Which portions of the financial process should be assigned to the State and which should be assigned to the local units? To what extent can the superior resources of the State and its central position enable it to serve as a qualified consultant to local governments? These and similar questions are at the heart of this study.

In attempting to answer these questions, this bulletin outlines the State and local relations growing out of the general laws respecting budgeting, assessing and collecting taxes, accounting, auditing, public

${ }^{1} \mathrm{~A}$ portion of this material was published as an article in the National $\mathrm{Mu}-$ nicipal Review, March 1942. In this bulletin the material is both revised and expanded.

${ }^{2}$ The author is indebted to many local and State officials as well as interested private citizens for assistance throughout this study. 
reporting, and the management of debts. At the conclusion, certain suggestions are made with a view of improving the existing system. ${ }^{3}$

\section{SOURCES OF INFORMATION AND METHOD OF HANDLING}

The information presented in this bulletin has been collected over a period of several years. The organization of the State government as related to the financial affairs of local governments was examined in detail. In this examination every effort was made to determine the number of State departments bearing some relation to local finances, the nature of these relations, the procedures followed, and the forms and reports utilized. Officials of the various departments contributed generously of their time and experience in making available the public records of their departments and in discussing the many problems involved.

Additional field work included interviews with county, city, and school officials as well as public spirited citizens. Budgets, tax rolls, general accounts, audits, financial reports, and records of indebtedness were analyzed in various sections of the State. At the same time the reactions of local officials to the present pattern of State and local financial relations in Texas were obtained. These interviews aided greatly in setting up the suggestions which are made at the end of this bulletin.

In making this study, it was necessary, at frequent intervals, to refer to the Constitution and laws of the State. In fact the basic provisions regarding State and local relations are necessarily embodied in the Constitution and laws. In addition, all available forms, reports, and guide books issued by the State departments in the conduct of their work with local officials were obtained and studied. These materials were of great assistance in obtaining an understanding of the legal phases of the study.

Finally, considerable attention has been given the solutions which have been adopted in other states. Each state has faced the same problem, and each state has attempted to devise suitable solutions. But some states have gone much farther than others in providing a coordinated set of relationships which take account of all aspects of the situation.

\section{FINANCIAL RELATIONS IN BUDGETING}

The first Texas budget law became effective in 1905. This law was quite limited in scope for it applied only to the counties having county auditors. Since Texas counties are not required to have auditors unless they have a valuation of $\$ 15,000,000$ or a population of 35,000 , the law probably never applied to more than 75 of the 254 counties at any time.

In 1931 the Uniform Budget Law was passed. This law applies to the counties, cities, and school districts as well as the State itself. Counties and cities are required to file copies of their annual budgets with the County Clerk and with the State Comptroller of Public Accounts (here-

${ }^{3}$ The Texas Agricultural Experiment Station has published a number of studies which are of value to one interested in the problems of State and local financial relations. These studies are listed in Table 2. 
after referred to as State Comptroller). The same requirement applies to supplementary or emergency budgets adopted during the year. Both common and independent school districts must file their budgets with the county clerk, but are not required by the budget law to file copies with any State official. In the case of common school districts the law apparently makes no provision for the adoption of supplementary budgets, but independent school districts may adopt supplementary budgets, copies of which must be filed with both the County Clerk and the State Comptroller.

The budget law provided no field force or other means of assisting local units in preparing and administering budgets. But local officials soon began to ask questions of the State officials and particularly of the State Comptroller with whom their relations had been most pleasant. Finally the State Comptroller in cooperation with the State Auditor and Efficiency Expert (hereafter referred to as State Auditor) managed to work out a standard county budget form, together with a manual entitled "Instructions for Preparation of County Budget Reports and Index to Laws Relating to County Finances." This manual has continued to be a valuable aid to officials despite the fact that it does not describe the forms now in use.

After two years of experience, a revised budget form was designed by the State Comptroller. This form simplifies the handling of many items and has been used by most counties even though various objections have arisen from time to time. A third revision of the county budget form was issued in time for the preparation of the county budgets for 1942 . This form was also prepared by the State Comptroller with the assistance of a committee representing the county officials and the East Texas Chamber of Commerce. 4 The latest revision of the budget form and the instructions emphasize the fact that items can be presented in several ways and still be uniform from county to county, provided adequate explanations are attached.

Many counties have followed the practice of typing or mimeographing their own budget forms instead of buying the State form from the stationery houses. This is particularly true of the larger counties. In numerous instances these larger counties have followed the classifications in the State form, but details under the various classifications have been expanded, and additional classifications appearing in the county accounts, but not in the budget forms, have been added. In reality, this is the way the standard budget form should be used, for essential uniformity is preserved while at the same time information peculiar to the particular county is revealed.

No State agency has prepared forms for cities, but the League of Municipalities once experimented with a form. Unlike the counties, the cities differ greatly a's respects the purposes of their expenditures, and it is extremely difficult to design budget forms which will suit their needs.

${ }^{4}$ For a more complete description of this committee and the procedure followed, see the section entitled "Improvements Made Through Associations of Local Officials and Other Organizations." 
In spite of the absence of a standard form, it should be possible for the officials of the various cities to prepare adequate budgets-provided agreement is reached as to the essential items of information which the budget should contain. In this connection, one of the studies prepared by the Bureau of Municipal Research of the University of Texas should be very helpful.5

The cities have been quite lax in observing the law as indicated by the number filing budgets. "At no time have more than one-third of the cities ever filed their budgets with the State Comptroller as required by law."6 The number filing seems to be decreasing steadily. In contrast to the cities, the number of counties filing budgets has remained fairly constant at approximately 80 per cent. 7

The school districts use a one-page budget form prepared and furnished by the State Department of Education. This form is only a summary, and the districts which are really interested in budgeting use it in that way. Some of these districts prepare rather complete budgets for their own use, but they file the standard form with the State Department. The Department has no field force to assist in preparing and administering the budgets, but some work has been done by other staff members. The Director of Information and Statistics spends most of her time in September and October each year assisting in the preparation of budgets. In addition, the 24 deputy state superintendents who are stationed at various points over the State are available to advise the districts which request advice on problems of budgeting. But the duties of the deputy superintendents with respect to the administration of the rural aid program largely restricts their efforts to the districts receiving such rural aids.

The State Department of Education is obliged to obtain copies of the budgets by exercising its authority to require "any necessary report" from the schools. Hence, a budget is required as a basis for distributing rural aids and per capita state apportionments. The districts have responded well, for more than 99 per cent have filed the budgets as requested. In the case of the few not filing budgets, the State Department has estimated the budgets on the basis of information from other sources at the State Capital.

In 1933 the Department of Education published a brief manual on school accounting and budgeting. In 1937 a revision of this manual was prepared, and portions have since been mimeographed and released.

\section{FINANCIAL RELATIONS IN ASSESSING AND COLLECTING TAXES}

The State of Texas has taken an active interest in assessing and collecting taxes, but only insofar as the work is confined to State taxes.

State ad valorem, poll, inheritance, and certain occupation taxes are

${ }^{5}$ A Budget Manual for Texas Cities, by Roscoe C. Martin, University of Texas Bulletin No. 3445, December 1934.

${ }^{6}$ State Control of Local Budgeting, by Stuart A. MacCorkle, Southwestern Social Selience Quarterly, September 1940 , p. 122.

${ }^{7}$ Budgeting in Texas Counties, 1931-1940, by H. C. Bradshaw, Bulletin No. 603, Texas Agricultural Experiment Station, September 1941, pp. 11-12. 
collected by the assessor-collectors elected in each county. In the collection of these taxes they are responsible to the State Comptroller. These same officials also collect the auto license fees, but they are responsible to the State Highway Department for these collections. Similarly the assessor-collectors collect the beer and wine permit fees, under the general supervision of the State Liquor Control Board. In addition, the county clerk collects the note stamp tax and makes his settlement directly with the State Treasurer. This information is shown in tabular form in Table 1.

Table 1. The Number of State Taxes Collected by County Officials, the County Office Making the Collection, and the State Agency Responsible Therefor.

\begin{tabular}{|c|c|c|}
\hline Name of State Tax & $\begin{array}{l}\text { County Office } \\
\text { Making Collection }\end{array}$ & $\begin{array}{l}\text { State Agency } \\
\text { Responsible }\end{array}$ \\
\hline Ad Valorem & Assessor-collector & State Comptroller of Public \\
\hline Poll & Assessor-collector & State Comptroller of Public \\
\hline Occupation & Assessor-collector & $\begin{array}{l}\text { State Comptroller of Public } \\
\text { Accounts }\end{array}$ \\
\hline Inheritance & Assessor-collector & $\begin{array}{l}\text { State Comptroller of Public } \\
\text { Accounts }\end{array}$ \\
\hline Auto license fees & Assessor-collector & State Highway Department \\
\hline $\begin{array}{l}\text { Beer and wine permit } \\
\text { fees }\end{array}$ & Assessor-collector & State Liquor Control Board \\
\hline Note Stamp tax & County Clerk & State Treasurer \\
\hline
\end{tabular}

In case the county desires to contract with an attorney for the collection of delinquent ad valorem taxes, the contract must be approved by both the Attorney General and the State Comptroller. The Comptroller's office provides mimeographed forms and instructions which outline the terms and conditions governing the preparation and execution of such contracts. In 1937 the State paid delinquent tax contractors $\$ 70,000$ in fees, while the counties paid these same contractors approximately $\$ 178,000$ during the same year. These contracts were in force in 73 counties during this period. This expenditure amounting to about a quarter of a million dollars could be saved by careful realistic procedures designed to secure the collection of ad valorem taxes by the county assessor-collectors before they become delinquent. In many instances taxes which are about to become delinquent can be collected through the use of ordinary business methods. For example, the use by the assessor-collector of additional notices, brief newspaper advertisements, and personal calls would prevent many delinquencies. In this connection it is well to note that the delinquent tax roll for prior years' taxes should serve as a good indication of those who are apt to allow their current taxes to become delinquent. While the assessor-collector should accept the responsibility for this work, as the law provides, the Commissioners' Court can lend effective support to the collector's efforts. Furthermore, much assistance can be secured from public spirited citizens, provided the county officials will take the time and trouble to explain the situa- 
tion. After taxes become delinquent the legal procedures involved in collection cause both delay and increased costs. Consequently, the goal in all counties (as well as in all other units of government) should be to keep the delinquent tax roll as small as possible.

The State Comptroller also has the responsibility of assessing the "intangible assets" tax which applies to certain types of utility companies. Following the determination of the tax on each company, the Comptroller's office prorates the assessment among the various counties in which the properties lie. These assessments are entered on the county tax rolls and the resulting taxes are collected by the county assessor-collector.

Similarly the State Comptroller is responsible for prorating the general property tax assessment on the rolling stock of railroad companies. This proration is made to the counties in proportion to the railroad mileage in each county, but the total state-wide assessment is actually determined by the county officials in the county where the company has its principal office.

The State Comptroller issues from time to time a booklet entitled, "Instructions for Assessing." The most recent edition bears this subtitle: “Giving the Statutory Requirements, Rules, and Regulations, Also the Special Instructions from the Comptroller Relative to the Assessment of State and County Taxes." In general, it may be said that an assessor who reads these instructions should know "what" he is supposed to do. But he may gain little or no idea of "how" to carry out his duties, for the instructions comment only incidentally on this point.

Some further instruction is provided the county assessor-collectors through the 14 ad valorem tax auditors, who check the county accounts relating to state ad valorem tax collections each year. The majority of these men have had years of experience in tax work and they are instructed to advise all officials who are interested in improving the conduct of their offices.

Every other year following the State and county elections, the State Comptroller in cooperation with the Assessor-Collector's Association sponsors a business meeting at the State Capital. This meeting lasts two or three days and is designed to acquaint the newly elected officers with their jobs. Many of the officials who remain in office for several terms keep on attending these meetings, and they assist greatly in explaining the work of the office.

The Comptroller's office is always well represented at the annual conventions of the assessor-collectors, and this provides an additional channel for instructional purposes.

The Comptroller carries on a vast correspondence with the county assessors. In addition, many of them come to the State Capital and talk over their problems in person. When new or unusual questions are brought up, the Comptroller's reply is mimeographed and distributed to all the counties. Questions involving legal decisions are referred by the 
Comptroller to the Attorney General and the opinions resulting are also mimeographed and distributed to all the counties.

From this outline, it is apparent that the State Comptroller does provide a great deal of advice and assistance to the assessor-collectors, despite the fact that he has no field force assigned specifically to that job. Nevertheless it remains true that there has been little attempt on the part of the Comptroller to issue general instructions covering the procedural or discretional work of the assessor-collector.

The Comptroller's office has little direct interest in the assessment and collection of city or school district taxes in Texas. Of course advice has been given when requested.

The State Department of Education has provided little or no assistance to school districts other than to print the laws applying to the assessment and collection of school taxes along with other laws.

\section{FINANCIAL RELATIONS IN ACCOUNTING}

Until recent years, the only mention of local accounts was found in the laws describing the records which were to be maintained. Following the passage of the Uniform Budget Law in 1931, it began to be realized that accounts may be an important tool of management. Accordingly, in 1933 the Legislature passed a law requiring that the State Comptroller design an accounting system for counties.

The bill which was introduced called for an appropriation of $\$ 25,000$, but this provision was eliminated before the bill became a law. Despite this lack of funds the Chief Clerk of the Comptroller's office with the aid of an Assistant State Auditor and one independent auditor managed to prepare a uniform system. The fact that these men were sufficiently interested to work under this severe handicap speaks well for the calibre of Texas officialdom.

The system so designed was printed by the company holding the State printing contract, and sample books containing each form, together with a manual of instructions, were sent to the county officials in 1937. The system is a good one despite the fact that it has several features which can hardly be used in practice; it has met a real need because it presents an over-all view of a county accounting system. One of the principal records provided is a multiple column ledger for the classification of receipts and disbursements. This record seems to have met a general need, for the number of counties using such distribution ledgers has increased tremendously since the system was released.

In a good many instances the counties have purchased distribution ledgers other than the one designed by the State, but ordinarily the variation is slight. There is no objection to this procedure for the persons who have studied the State system and have found objections to it are generally keeping accounts which will supply the same information. This fact suggests that uniformity should consist in securing agreement as to the essential classifications of accounts while at the time providing 
considerable flexibility. Under such a set-up officials can expand the detail within the essential classifications, and can introduce such additional classifications as may be necessary to describe activities peculiar to the particular county. As a matter of fact, the uniform county accounting system prepared by the Comptroller is supposed to be used in this way. In describing the system, the Comptroller says in part: "In designing the Uniform System of Accounts, as recommended herein, the needs and problems of the smaller counties that do not have county auditors have been kept in mind. The system has been designed, however, so that it may be used by the larger counties, and may be expanded to meet the requirements of even the largest counties in the State."8

It should be emphasized that the State of Texas, through its agent, the State Comptroller, has made no demands upon the counties as respects accounting systems. The system was prepared and made available for purchase through the stationery houses. Local officials are free to adopt the system, or not, as they may decide.

Insofar as the cities are concerned, the State has provided no direction at all as to accounts and record keeping. But the League of Municipalities and the Municipal Finance Officers' Association has provided an "Accounting Manual for Texas Cities and Towns." This manual was released in 1938 .

The public schools of Texas are not required to keep any specific set of books. But school officials find it necessary to keep certain accounts in order to provide the information for various reports which are required by the State. The State Department of Education has published some pamphlets relative to the handling of accounts, but no field force is maintained, and, therefore, the degree to which such suggestions are utilized is dependent on the school authorities.

In 1930 the General Education Board made a grant to the State Department of Education for the purpose of studying the possibilities of reorganizing the public school system of the State. The representative of the General Education Board, Mr. H. F. Alves, soon determined that the accounting systems would have to be improved before worthwhile reorganization studies could be made. To this end Mr. Alves assisted in the preparation of instructions regarding the content and arrangement of school accounting systems. 9 Following this work by the State Department, one of the stationery houses designed and published a school accounting system which has been widely used by the school authorities. This system will provide the information needed for the budget and the annual reports.

Officials of the State Department of Education express a belief that school accounting has improved considerably in recent years. One explanation is that several of the colleges have provided two- or three-day meetings each summer on the subjects of accounting and related problems of school finance.

\footnotetext{
${ }^{8}$ Instructions For Operation of the Uniform Accounting System For Counties, p. 1 .

${ }^{9} \mathrm{Manual}$ of Ins+ructions in Financial Accounting, Bulletin No. 316 of the State Diepartment of Education, January 1933.
} 


\section{FINANCIAL RELATIONS IN AUDITING}

\section{Audits of Local Accounts by the State}

The State has taken relatively little interest in the auditing of local accounts. Auditing work is largely confined to the checking of State taxes collected by the county officials, and the pre-audit of fees claimed by county and precinct officers in State cases.

The State Comptroller has 14 traveling auditors assigned to the task of auditing the county assessor-collectors. These audits are confined to the State collections of ad valorem, occupation, poll, and inheritance taxes. By limiting the job to this degree the auditors are able to check each county each year.

The county assessor-collectors are responsible to the State Highway Department for the collection of auto license fees. The State provides the license plates and audits each county at or near the end of the normal period during which licenses are purchased.

The issuance of wine and beer permits through the assessor-collector is checked by the State Liquor Board in two ways. First the license granted in the county must be approved by the State authority, and second the liquor enforcement officers and the local police examine the licenses displayed.

The note stamp tax is collected for the State by the county clerks. At the time the stamp is affixed, the clerk collects for the stamp which he has already purchased directly from the State Treasurer. The State has never made local audits of these collections.

The State has, in recent years, taken an active interest in the fees claimed by county and district officers who assist the courts in trying State cases. In 1931 the Legislature created a Joint Audit Committee composed of auditors from the offices of the State Comptroller and the State Auditor. In 1936 the Joint Audit Committee reported that an audit of $\$ 920,000$ of claims against the State resulted in an actual saving to the State of $\$ 476,000$. Of this amount, $\$ 329,000$ of claims against the State were refused, and $\$ 147,000$ in amounts due the State were collected. An additional amount of $\$ 366,000$ in sums due the State from fee officers was also set up; consequently, the total actual and "contingent" saving from this audit amounted to $\$ 842,000$, that is $\$ 476,000$ plus $\$ 366,000.10$

As a result of this work, a pre-audit of fee accounts has been provided in the State Comptroller's office. Approximately four people are now employed in pre-auditing the $\$ 750,000$ to $\$ 1,000,000$ in fees which are claimed by local officials each year. When it is impossible to settle a claim by correspondence, the chief claims auditor makes a trip to the county and goes over the matter in person. These trips require about one-fourth of his time and are regarded as indispensable for they provide

\footnotetext{
${ }^{10}$ Reorganization of Counties, by H. C. Bradshaw, Journal of Farm Economics, August 1937, p. 749 .
} 
an opportunity to instruct and advise the officials involved. This preaudit has undoubtedly saved a great deal of money and has been the means of improving the fee accounts of local officials. The conditions existing before this procedure was installed were reported by the State Auditor in 1933.11

The State provides no auditing service of any kind for the cities of Texas. Moreover the general law includes only the slightest reference to the problem. While the law allows cities to employ auditors or to make contracts for independent audits, no direction or advice is provided by the State as to the auditing services needed.

Similarly, almost no auditing service is provided for the school districts of the State. The State Auditor is required to pass upon the applications of the districts for equalization aids for salaries, transportation and tuition. These aids are paid from the general fund of the State. For the most part these audits have consisted of examinations of the requests which are filed, together with an examination of the budgets, school census figures, and other information filed by the districts. The State Auditor has never had more than three men to assign to this audit, and field examinations have never been possible.

The State Department of Education has provided some measure of auditing as regards the scholastic enumeration. While this is not an audit of finances, it is closely related, for the number of scholastics determines the amount of State apportionment each district is to receive. This is by far the largest State aid paid to the public schools of the State.

\section{Audits of Local Accounts by Independent Auditors}

The State law applying to local audits by independent audit firms merely prescribes the method by which such audits may be secured, and does not describe the content of any audit. The local unit must decide for itself as to the need for an audit and the type of audit which should be made. The customary practice is to take bids for audits and to award the contract to the lowest and best bidder.

The use of specifications for audits has gained relatively little ground in Texas. For the most part, the scope and content of the audit is described only in the bids which are filed by the various auditing firms. There are a number of units, however, which have prepared specifications showing exactly what was to be done by any auditor who might be employed. The first State Auditor also prepared specifications for a detailed audit. These specifications have been used in numerous instances.

In reality, bids and specifications are closely related. That is, bids, if taken, should be on the basis of specifications showing exactly what the auditing firm is to do. In following this procedure, qualified auditors can bid on a per day basis but specify the maximum total price. The resulting contract should also specify that additional work found to be

${ }^{11}$ Biennial Report of the State Auditor and Efficiency Expert, March 1933, Volume 37, p. 25 . 
necessary but not included in the specifications should be brought to the attention of the governing board. Then in case the governing board approved the performance of such work, the payment to the auditor would be increased proportionately.

In order to be sure that the specifications are followed, public officials should keep in touch with the auditor and his assistants during the conduct of the audit. An official who is familiar with the specifications and the contract should know about how much time is being spent on the major portions of the job. This knowledge combined with a careful study of the auditor's report should go far towards insuring compliance with the specifications. In addition, the auditing profession should accept considerable responsibility for enforcing such compliance on the part of its members.

The audit report itself might well contain a copy of the specifications and a copy of the contract as well as any correspondence between the contracting parties. Certainly the provision of this information would make the report more useful to all concerned.

Unfortunately it is the exception rather than the rule to find an audit report which reveals exactly what was done and how the task was executed. In far too many instances an examination of the price paid, together with the time spent in the local unit, suggests that the audit was little more than a summary of the year's business prepared from the general accounts. Sometimes these audit reports are exceedingly well written and, consequently, they may reassure the local officials to an extent which is hardly justified by the scope of the audit made. Furthermore, the provision of inadequate audits at a very low price in dollars, works a hardship on the qualified independent auditors who are striving to assist public officials through the provision of first class auditing services. As compared with an inadequate audit which is hurriedly made, the adequate audit requires far more time to complete, and, consequently, costs more in terms of dollars and cents. But in terms of services rendered the adequate audit is the most economical for it actually gives the governmental unit the protection and assistance for which payment is made.

During the year 1935 only 164 of the 560 cities and only 136 of the 254 counties employed private auditing firms for any sort of audit. In numerous instances, however, the audits covered two or more years. The 164 cities paid $\$ 55,745$ for these audits while the 136 counties paid $\$ 79,558$ for these services.12 These figures indicate that cities and counties are making efforts to secure the auditing services which they need. But it must also be mentioned that a considerable number of cities and counties are audited only at irregular intervals, and some have never purchased an audit of any kind.

The foregoing description makes it evident that auditing in Texas needs to be expanded and improved. The audits made by the various State departments are useful and necessary, but they cover only a small

${ }^{12}$ Unpublished data secured from the records of the Texas Highway Planning Survey. 
portion of local governmental business; they do not begin to satisfy the need of local governments for auditing services. Further, the authority of local governments to secure audits through contracts with private auditing firms has failed to produce uniformly good results. Some local governments do not secure audits at all and others frequently secure inadequate audits that fail to provide the protection which auditing services should afford. State and local officials in cooperation with the auditing profession should work together in improving this situation.

\section{FINANCIAL RELATIONS IN PUBLIC REPORTING}

Although a casual reading of the law indicates that all units of local government are required to make financial reports to the State, a closer examination reveals that these reports fail to provide a complete picture of local finances.

Report on Taxes and Indebtedness of Local Units of Government in Texas. Each unit of government is required to make an annual report oî tax collections and indebtedness on forms designed and furnished by the State Auditor. These forms are sent to the county auditor, or to the county clerk in counties having no county auditor, and this officer, in turn, supplies the cities, school districts, and water districts with the proper forms. When completed, each unit returns the forms to the county auditor or clerk. One copy is kept in the county and the other is forwarded to the State Auditor. With respect to taxes, this report ordinarily shows only the ad valorem tax situation including the current collections, the delinquent collections, and the delinquent taxes outstanding. In addition, it shows the current and time debt outstanding. (This report contains no information at all with respect to the type and amount of expenditures.) The State Auditor compiles a state-wide report based on the information submitted from each county. The usefulness of the compiled report is limited by the fact that many important revenues such as automobile Iicense fees are omitted; it, therefore, does not give a complete picture of the receipts of any unit of government. Furthermore, it must be noted that because of the numerous differences in fiscal years, the report dues not cover the same 12 months for all units. In fact the state-wide report merely states that it is for the "last fiscal year ended prior to September 1." In spite of these limitations the report is a valuable source of information, particularly to the security dealers who handle bonds issued by the local units of government.

State Comptroller's Report on Indebtedness. A second report is required of each local unit of government as of June 30 annually. This report is made to the State Comptroller on forms furnished to each unit by that office. It is confined to a statement of the outstanding indebtedness and sinking fund assets. This report has been ignored by many local units and in general has been of little value. In 1940, the forms and instructions were revised, and the number of units filing the reports in- 
creased considerably. But it is well to note that in distributing the revised form, a letter of explanation was attached, and later a follow-up letter was used. Consequently, the increase in the number of reports filed may have been due to the increased activity of the Comptroller's office. A tabulation of the reports received from local units is contained in the annual report of the State Comptroller of Public Accounts.

Annual Report of District, County, and Precinct Officials. There is a third annual report which is made only by district, county, and precinct officials who are responsible for the collection of fees for the performance of certain duties. Each official is required to report the source and amount of each item of official income including all fees collected. In addition, the report itemizes all fees "earnea" but not collected during the year. A copy of each report is filed with the district clerk and a second copy is filed with the county auditor, or with the Commissioners' Court in counties having no auditor. After all reports have been received, the district clerk in each county is responsible for forwarding a third copy of each report to the State Auditor. No state-wide compilation is made of the individual reports. The State Auditor's office has relatively little time to devote to these reports, but a real effort is made to obtain them through correspondence. Investigation reveals that about 80 to 85 per cent of the officials make these reports' each year.

Annual Report of School Superintendents. The superintendent of schools in each county and each independent school district is required to make an annual report to the State Department of Education on forms prepared and furnished by the State. In addition to financial data this report contains much general information relative to the operations of the school system. The classifications of receipts, expenditures, and indebtedness are in conformity with the recommendations of the National Office of Education, and are, therefore, comparable with similar reports in other states.13 But the accuracy and completeness of these financial statements is largely dependent on two factors, namely: the accounting systems of the individual school districts and the care exercised in filling in the information required. The period covered is the regular school fiscal year ending August 31. Much of the information contained in these reports from individual school districts is summarized in the biennial reports of the State Department of Education. While the information obtained in this manner is subject to numerous criticisms, it remains true that the school districts are the only units of local government whose complete operations are summarized and reported upon by a State agency.

From the foregoing description, it is apparent that even when all sources of information at the State Capital are utilized it is impossible to secure a complete picture of the receipts, expenditures, and indebtedness of the local units of government. This is absolutely true of the

\footnotetext{
${ }^{13}$ See the Biennial Report of the State Department of Education, 1930-32, p. 121.
} 
cities and water districts and it is true to a considerable degree of the counties. The school districts, as has been explained, do have a reporting system which provides an over-all summary of operations. These weaknesses in public reporting make it difficult, if not impossible, for the State Legislature to obtain complete information relative to the finances of local units of government. The same thing is true of public officials and the citizens as a whole.

\section{FINANCIAL RELATIONS IN THE MANAGEMENT OF DEBTS}

The issuance of bonds must be approved as to legality by the Attorney General of the State of Texas. No forms are prescribed for the presentation of applications, but the information required is set forth in the law. In numerous instances the companies which are printing the bonds also prepare the necessary forms to be filled out by the local officials and sent to the Attorney General.

The information submitted must show that all the territory of the county or other unit of government has been legally acquired and that all such territory is behind the existing debt as well as the contemplated increase in debt. In addition, it must be shown that the proper election procedures have been carried out and that the debt is within the constitutional and statutory limitations governing the creation of debt by local units of government.

With regard to tax rates, the evidence submitted must show that a rate sufficient to service the indebtedness exists within the limitations prescribed, and that the necessary portion of such rate is levied. Finally the printed bonds must be submitted to the Attorney General for approval as to form.

It should be emphasized at this point that the Attorney General's approval is limited to legal questions. If the evidence sñows that the unit of government has complied with all constitutional and statutory requirements, approval must be given.

The foregoing comments apply equally to counties, cities, road districts, school districts, and water districts organized in Texas.

Nevertheless, in the case of school districts, the Attorney General has exercised some discretion, in recent years, in calculating the amount of taxes which can legally be collected to service the debt in question. After calculating the amount of taxes which the available tax rate would yield, a deduction of 10 per cent has been made for delinquent taxes. Thus, if the maximum available bond rate would produce a tax levy of $\$ 10,000$, this amount would be reduced to $\$ 9,000$ by the allowance for delinquent taxes. This procedure is evidently not contemplated in the law, but so far it has not been questioned.

With further regard to school districts, it has become common practice for the State Legislature to pass validating statutes stating that all territory now within the area of certain school districts (listed by name) 
has been legally acquired. This procedure corrects any deficiency which may have occurred in the acquisition of territory.

Following approval by the Attorney General, each issue of bonds must be registered by the State Comptroller. This is a ministerial duty which is performed by entering the legal description of the issue in a bound volume known as the "bond register." This requirement applies equally to the issues of all units of local government within the State.

The State Board of Education is given the privilege under the law of purchasing the bonds issued by local governments simply by meeting the highest bid which has been made by other organizations. All bonds purchased become the property of the permanent school funds. If the Board does not desire to purchase the bonds, a waiver is given which permits the unit of government to sell the bonds through the regular bond houses. This procedure is sometimes criticized on the grounds that local officials find it difflicult to obtain bids from the bond houses. This is true because the bond houses must bear the expense of investigating and making bids, but have no assurance that they will be allowed to handle the issue. Undoubtedly the bases for this criticism could be overcome by a suitable revision of the procedures through which bonds are purchased for the permanent school funds.

In the case of county and road district bonds issued to build roads which have become a portion of the State Highway System, some advice is given the counties by the Board of County and District Road Indebtedness. This ex-officio board is composed of the State Highway Engineer, the State Comptroller, and the State Treasurer. The permanent staff of the Board is headed by an accountant and is charged with the duty of administering the one cent of the four cent gasoline tax which has been devoted, since 1933 , to the retirement of local bonds used to build state highways. Each year, prior to budget making time, the Board provides each county with a statement showing the amount of principal and interest due on each issue which receives State assistance. In addition the statement shows the amounts of principal and interest of each issue which must be paid by the State and the county or road district respectively. This statement allows the county officials to calculate exactly the amount which the county must collect for debt service and to set the tax rates accordingly. As each payment becomes due, the Board reminds the county, and the county sends its check to the Board office at the State Capital where it is combined with the gasoline tax money and sent to the State Treasurer to meet the payment.

This use of the gasoline tax money has allowed a reduction in total ad valorem tax collections of the counties and road districts which has exceeded 20 per cent in recent years. This has meant a real relief to the taxpaying property owners.

The chief defect in State and local relations with respect to debt is that no State agency is charged with the responsibility of advising and assisting local units on all problems of public indebtedness. A qualified State agency should be in a position to provide constructive advice as to 
the desirability or necessity of creating debts for various purposes, the type of bonds to be used, the various methods of selling bonds, and the management and retirement of debts already outstanding. In the case of local governments which are in poor financial condition, the State agency should have authority to prepare, and if necessary to administer plans to improve such financial condition. Such plans should assist numerous local units in preventing defaults on indebtedness and should assist units already in default in achieving a sound financial condition. The State of New Jersey has developed this approach and the results have been gratifying. ${ }^{14}$ To be most effective, the agency or staff which is charged with assisting local governments with their problems of debt administration, should operate in close cooperation with the staff responsible for assisting with other financial problems. In fact the same staff might well be responsible for many of the related activities discussed in this bulletin.

\section{DIFFERING FISCAL YEARS COMPLICATE THE PROBLEM}

No discussion of State and local financial relations in Texas would be complete without reference to the confusion caused by differing fiscal years. The State and the school districts operate on a budget year ending August 31, the counties use the calendar year, and the cities and special districts use years ending on various dates. About one-half of the cities use a year ending in April.

The tax collection year for the State, the counties, and the school districts runs from October 1 to June 30 . This means that portions of two tax collection years will be included in the State, county, and school budget year.

Likewise, cities organized under the general law are required to use the tax collection dates of the State and county, if they desire to apply penalty and interest on delinquent taxes. This often means that the city tax collection year does not coincide with the budget year. Similarly, in two cases, the reports required to be made to the State may not agree with the periods used for any other purpose.

These differences in fiscal years destroy most of the possibilities of working out the inter-relationship between the local units and the State insofar as payments of money are concerned. For example, the payments by the State to the county fee officials are reported in the Comptroller's annual report for a year ending August 31. But the county officials report these same fees to the State auditor for the calendar year. Similarly, the State tax collections from each county are reported on a year ending June 30 , while the State aids to the local units are reported for a year ending August 31.

The accumulation of accurate financial data on all units of government in the State could be greatly simplified by the adoption of measures

\footnotetext{
${ }^{14}$ State Supervision in New Jersey Over Municipalities in Unsound Financial Condition, by John H. Marion, American Political Science Review, Vol. 36, No. 3, June 1942 .
} 
designed to place all units on the same fiscal year. While it might be difficult to eliminate all differences, the number of fiscal years now in use could be reduced by a large percentage.

\section{IMPROVEMENTS MADE THROUGH ASSOCIATIONS OF LOCAL OFFICIALS AND OTHER ORGANIZATIONS}

One important point which has not been sufficiently emphasized is that the various associations of public officials have done much to improve the conduct of State and local financial relations. The work of some of these associations has already been mentioned with approval. For example, in the section on assessing and collecting taxes, it is stated that the Comptroller's office has cooperated with the county assessorcollectors' association in holding a short training school following each election.

The County Auditors' Association of Texas has devoted much time to discussions of the county budget, including both its preparation and administration. The East Texas Chamber of Commerce through its Tax Director has also devoted considerable attention to county budgeting and related financial problems in all local governments in the 70 counties of the area. In May 1940 the State Comptroller of Public Accounts and the Tax Director of the East Texas Chamber of Commerce called together a small group for the discussion of county budgeting problems. This group included county judges and county auditors as well as private independent auditors and tax specialists. As one result of this meeting a committee was appointed to revise the forms and instructions for the preparation of county budgets. In making these revisions the committee had the benefit of the suggestions agreed upon by the entire group.15 The resulting revisions were accepted, with certain modifications, by the Comptroller of Public Accounts, and made available to the counties. This approach to the solution of common problems deserves to be used more frequently. It is a democratic method of finding workable solutions.

The city officials of Texas have cooperated in preparing "An Accounting Manual for Texas Cities and Towns" which was released in 1938. In preparing this manual the officials cooperated through membership in two associations; namely: the League of Texas Municipalities and the Municipal Finance Officers Association.

Further, the League of Municipalities and affiliated organizations including the University of Texas and the State Board of Vocational Education have recently employed two men to conduct in-service training work. One man is limited to assessing problems, and the other man is assigned to the broad field of city finances. The schools conducted over the State are open to city, county, and school officials as well as interested citizens. As a part of this program, an assessor's manual has been prepared and possibly other manuals will be developed later.16

\footnotetext{
${ }^{15}$ The committee was composed of P. L. Marquess, President of the County Auditors' Association, and H. C. Bradshaw, Economist in Farm Taxation, Texas Agri-

cultural Experiment Station. 1941.
} 
The State Teachers' Association through its director of research has devoted much attention to problems of school finance. In this work the Association cooperates closely with the State Department of Education. In addition there are several groups of teachers and superintendents which hold meetings at least once a year. Each summer Texas A. and M. College is host to two such groups; namely: The Association of County Superintendents and The Texas School Administration Conference. The latter is composed chiefly of the superintendents of city school systems. Each of these groups devotes considerable time to discussions of State and local school finance and particularly to the methods used by particular districts in solving their financial problems. These discusions are undoubtedly helpful to those in attendance.

Finally, it must be mentioned that the magazines published by certain of these organizations serve as a medium through which the solution of financial problems are reported. The County Judges' and Commissioners' Association sponsors a monthly magazine called "County Progress"; the League of Municipalities publishes "Texas Municipalities"; and the State Teachers' Association publishes the "Texas Outlook."

The Texas Society of Certified Public Accountants has made recommendations relative to the conduct of public audits. More specifically the Society, through a committee, has suggested a uniform certificate or letter of comment. Further, the committee recommends that the forms, terminology, and accounting principles outlined by the National Committee on Uniform Accounting be followed in auditing cities, counties, and independent school districts in Texas.17

The Texas Section of the American Society of Civil Engineers has prepared and published a "Model Charter For Texas Counties." This charter, prepared by a committee on public administration, deserves the careful consideration of all citizens interested in the improvement of county government. Such a charter could be adopted by a county under the provisions of the home rule amendment adopted in 1933 and subsequent enabling legislation.18

Other associations and other activities of these associations might be mentioned, but enough has been said to emphasize the importance of these groups in any program which is designed to improve State and local financial relations. These groups have seen the problem for a long time and have made considerable progress in devising solutions. But they cannot do the job alone. Public officials must spend most of their time on the job, and, therefore, cannot carry the results of their work directly to the officials of other units of government. In view of this fact it is desirable that the State provide an organization through which the nowledge gained in the best managed local governments can be organized and passed on to less fortunate public officials. The State is peculiarly adapted to this position because it possesses far more resources than

${ }^{17}$ The Texas Accountant, official bulletin of The Texas Society of Certified Public Accountanis, June 1038 .

${ }^{18}$ Model Charter for Ṫexas Counties, published in The Texas Engineer, University Station, Austin, Texus. December 1939. pp. 9-22. 
any of the local governments. Furthermore, the State, by its very nature, must have financial dealings with all units of government in the State.

\section{SUMMARY AND CONCLUSIONS}

The financial problems of the State and local governments are related in a variety of ways. The counties assess and collect certain State taxes, the school districts receive State aids voted by the Legislature, and all units are subject to State laws on budgeting and related financial procedures. If wasteful expenditures lead to excessive taxation in one unit of government, the difficulty of collecting taxes increases in other units occupying the same area. On the other hand, good financial practices in one unit of government tend, by example, to promote good practices in other units.

The problem of State and local financial relations, therefore, exists and cannot be avoided. The officials of the two levels of government must consult each other, must initiate actions which affect each other, and must share certain responsibilities. The resulting relations between public officials and the governments which they represent are not an end in themselves, but they assist materially in operating the 7,685 units of government in Texas. Furthermore, these relations provide tangible opportunities for the improvement of government in all its phases.

The present pattern of State and local financial relations suffers greatly from a lack of coordination. On the one hand, actions which need to be taken are ignored, while on the other hand, actions which only partially satisfy a need are duplicated. While each session of the Legislature is confronted with numerous bills affecting this situation, relatively few of the bills attempt to coordinate the many related phases of the problem.

In order that the pattern oi financial relations may be improved, it is necessary to obtain a clear picture of the purposes involved, the machinery utilized, and the results realized. Much basic information relative to the problem is contained in this bulletin; additional information which cannot be reported in a brief publication may be secured by studying the provisions of the law and by consulting State and local officials and their financial reports.

In making the analysis necessary for the preparation of this bulletin, much difficulty was occasioned by the great number of fiscal years employed by State and local governments. The fact that tax collection years do not agree with budget years, and that neither set of months agrees with the 12 months used for other purposes makes the compilation of accurate financial data exceedingly difficult, if not quite impossible. Much of this difficulty could be eliminated by the adoption of measures designed to secure the use of the same fiscal year for all purposes. While it might not be possible to eliminate all differences, the number of fiscal years now in use could be reduced appreciably.

Furthermore, this analysis reveals that the system of budgeting and reporting falls considerably short of providing complete and comparable 
information respecting the finances of State and local governments. For example, reports of county indebtedness are duplicated, while county expenditures are not reported at ail. These duplications might be eliminated and the omissions corrected by a simple revision of the laws involved. Such a revised law would continue the budget which is already required of each unit, but, in addition, would require the submission of an annual report following the same classification of accounts as the budget. This annual report would reveal all the receipts, disbursements, and outstanding debts of the county, city or school district. The State agency receiving this report could then compile an annual report reflecting the data submitted by each local unit of government. In addition to providing much needed information of a comparable nature, these revisions would eliminate the two partial reports on taxes and indebtedness and indebtedness and sinking fund assets.

Another important factor in the problem of State and local relations is the accuracy and usefulness of the accounts maintained by the units of government. While the accounting systems have been improved considerably in recent years, there is still room for improvement-particularly in the development and use of accounting information in facilitating good management of governmental services.

In order that accounts may be verified thereby protecting both public officials and the public, it is necessary that adequate audits be made. This study indicates that relatively few governmental units are receiving the type and amount of auditing services needed. Some means should be found of expanding and improving the status of public auditing in order that it may be of fullest possible value to all concerned. This result might be secured by one of several methods or by a combination of such methods. Certainly the State and local officials in cooperation with the auditing profession should strive to make adequate auditing services available to all local governments in the State.

With respect to assessing and collecting taxes, the role of the State government in providing general information as well as technical guidance might well be expanded. For example, utility and similar properties which frequently operate in several local units of government and are extremely difficult to assess locally, could be appraised by the State. Under this system recommended values resulting from the appraisals would be prorated to the local governments having such property. Furthermore, provision is needed for the equalization of property assessments as between counties. In the absence of such equalization, county officials are inclined to assess at a low percentage of true value in order that taxpayers may pay as little State taxes as possible. This competitive underassessment penalizes the State through loss of revenue, penalizes many taxpayers through the inequalities so created and is especially hard on the small counties because they must assess at a relatively high percentage of true value in order to have enough money to finance local government. 
On the basis of this study, it is suggested that the State could render a real service by accepting additional responsibility for the guidance of local governments with respect to the management of debts. The staff utilized for this purpose would have the responsibility of determining the conditions under which bonds might safely be issued by the local units of government, and of carrying out an educational program designed to place such information in the hands of the officials and the public. The agency might also assist in the sale of bonds particularly in the case of the smaller units which seldom issue bonds and may have difficulty in securing reasonable prices. In the case of local governments which are in default or are in danger of defaulting, such an agency could be of great assistance in formulating and administering plans to improve the financial standing of the unit.

Finally, on the basis of this study, it is evident that there is need for a central State organization to administer an improved program of State and local financial relations. Certainly the provision of such an organization would greatly simplify the administration of the several related activities which are now found under several departments. If it is desirable to place such a central organization within an existing department, the State Comptroller's office appears to be a logical choice. This is true because the State Comptroller already has some responsibility under the law for each financial activity which has been discussed in this bulletin. While a majority of the work which has been discussed might well be placed under such a central organization, it would not be necessary to remove all responsibility from other departments.

In order to be most effective, a central organization would need an adequate field force composed of well-trained and experienced persons capable of learning from as well as instructing local officials. There are many local officials and employees who have the knowledge, the vision and the interest to perform such work effectively. Further, it is suggested that the State have no authority to dictate local actions. This would mean that the department and its field men would be under the necessity of gaining the confidence and support of local officials and the public by demonstrating ability to render genuine assistance. By this approach the cooperation of State and local officials in solving common financial problems would be encouraged.

There is considerable evidence that such an organization could save more than enough money to pay for its operations. For example, a recent study made by the Texas Agricultural Experiment Station shows that the State pays something like $\$ 70,000$ annually to special delinquent ad valorem tax collectors. In addition, the counties paid approximately $\$ 178,000$ to these same contractors for the year in question. These two sums, totaling $\$ 248,000$, could be saved by procedures which would secure the collection of these taxes by the county tax collectors who are elected for this purpose. It should be noticed that these figures do not take into consideration the amounts paid delinquent tax collectors by 
the cities, school districts, and water districts. Information on these payments is not available.

One of the most important duties of a State organization of this kind would be to serve as a clearing house for the exchange of ideas, methods, and procedures. Many local officials are doing good jobs in their respective communities; the knowledge which they have gained should be made available to other officials over the State. This should tend to raise the level of performance to that found in the best managed units of government.

In order to render the greatest possible service the State organization should cooperate with the various associations of county, city, and school district officers, for each association is interested in improving the training and ability of its members. It cannot be emphasized too strongly that the job of improving State and local finances and of creating and maintaining effective relations between the two levels of government, requires a combination of forces for its accomplishment. This is true because each unit of government, including the State, has need for improvement in its organization and procedures. A well organized program should provide for improvements in both the State and local governments through the use of methods which are mutually sponsored in a spirit of understanding and confidence.

TABIE 2.-STUDIES OF TAXATION AND GOVERNMIENT PREPARIED BY THE TEXAS AGRICUITURAI EXPERIMENT STATION

These studies contain much information of value to those interested in State and local financial relations. All publications are furnished free of charge. Make youx request by postcard or letter to I. P. Gabbard, Agricultural Fxperiment Station, College Station, Texas.

Bulletin No. 458, Inequalities in Taxation of Farm Iands and City Property Due to Scope and Method of Assessment, by I. $\boldsymbol{P}$. Gabbard, 1932.

Bulletin No. 505, Relative Importance of Intangible Property in Texas, by I. P. Gabbard, 1935.

Bulletin No. 507, Tax Delinquency on Farm Real Fstate in Texas, by I. P. Gabbard, 1935.

Bulletin No, 512, Trend of Taxes on Farm and Funch Real Fstate in Texas, by I. P. Gabbard, 1935.

Bulletin No. 540, Possible Savings Through Changes in Iocal Government, by H. C. Bradshaw and I. P. Gabbard, 1937.

Bulletin No. 603, Budgeting in Texas Counties, 1931-1940, by H. C. Bradshaw, 1941.

Progress Report No. 608, The County Unit System of Road and Bridge work in Harrison County, Texas, by H. C. Bradshaw, 1939.

Progress Report No. 705, Delinquent Tax Contracts in Texas Counties, by H. C. Bradshaw, 1940.

Progress Report No. 745, Good County Roads Save Money in McIennan County, by $\mathbf{H}$. C. Bradshaw, 1940. 